\author{
IZABELA LEWANDOWSKA \\ ORCID https://orcid.org/0000-0003-0853-7913 \\ GRACJAN GiżEJEWSKI \\ ORCID https://orcid.org/0000-0003-3542-6071 \\ Uniwersytet Warmińsko-Mazurski w Olsztynie
}

\title{
ORAL HISTORY W ROSJI I POLSCE - PRÓBA PORÓWNANIA
}

\section{Oral history in Russia and Poland - comparison attempt}

WyRAZY KLUCZOWE: historia mówiona (oral history), archiwa historii mówionej, historia społeczna, Rosja, Polska

KEYwORDs: oral history, archives of oral history, public history, Russia, Poland

Summary: The aim of this article is to note the similarities and differences in the oral history of Russia and Poland. It is based on academic literature and the public presence of oral history in both countries, and analyzes the development of research on oral history as well as shows the presence of this method in academic studies. It also presents the non-governmental activities of social organizations. The comparative studies arrive at the conclusion that oral history centers in Russia are developing vigorously on the institutional (academic) level, whereas in Poland more on the council and civic levels. It is important to establish a collaboration between researchers from both countries in order to improve the method and run common projects on that matter.

\section{Historia badań nad oral history}

Oral history to metoda naukowa wykorzystywana w badaniach współczesnej historii na całym świecie. Jej początki datuje się na lata 20. XX w. w Stanach Zjednoczonych, potem rozwinęła się w Wielkiej Brytanii, Włoszech, Niemczech. W polskiej literaturze naukowcy-oraliści odwołują się głównie do badań podejmowanych w tych czterech krajach. Nie ma w języku polskim artykułu prezentującego dokonania radzieckiej/rosyjskiej oral history. Celem niniejszego tekstu jest więc przybliżenie polskim czytelnikom tego zagadnienia, a także próba porównania badań rosyjskich i polskich. W niektórych aspektach podejmowane działania są podobne, $\mathrm{w}$ innych zaś różne. Oczywiście, będzie to tylko zarys problemu, który wymaga pogłębionej analizy. Ze wstępnych badań komparatystycznych wydaje się on bardzo interesujący, a badacze obu krajów mogą się wzajemnie inspirować i podejmować wspólne inicjatywy. 
W Rosji pierwsze kroki w zapisywaniu przekazów ustnych podjęto na początku XX w. Po przejęciu władzy przez bolszewików w październiku 1917 r. zapis źródeł został poparty przez państwo. Z inicjatywy Włodzimierza Lenina został utworzony dział propagandy gramofonowej, w którym przechowywano przemówienia przywódców radzieckich. W 1918 r. powstał Instytut Żywej Mowy. Podczas 10 lat jego działania udało się zebrać 600 nagrań. Od 1920 r. aktywnie prowadzono zapisy wspomnień uczestników ruchu rewolucyjnego. Powołano wówczas komisję ds. studiowania materiałów historycznych związanych z rewolucją październikową i Rosyjską Partią Komunistyczną. Na początku badała ona źródła mówione, które pozwalały zachować pamięć o wydarzeniach odnoszących się do rewolucji. Idea opisania oddolnego życia w tamtych czasach była bardzo popularna, szczególnie że przybliżano społeczność bolszewików czy żołnierzy Armii Czerwonej. Niestety, w 1928 r. komisję zlikwidowano jako zbyt groźną dla nowo kształtującej się władzy (Melnikova 2006, 4). W 1932 r. powstało Centralne Państwowe Archiwum Nagrań Dźwiękowych, ale przez wiele lat jego działalność była ograniczona. Praktyka zbierania ustnych przekazów ponownie ożywiła się po napaści Niemiec hitlerowskich na ZSRR, czyli po $1941 \mathrm{r}$. Pracownicy komisji specjalnej chodzili na front, odwiedzali szpitale i spisywali historie żołnierzy. Zebrano w ten sposób kilkadziesiąt tysięcy nagrań, z których 4 tys. przechowuje się obecnie w Archiwum Naukowym Instytutu Historii Rosyjskiej (Орлов 2014).

W Polsce zaczęto interesować się zbieraniem relacji ustnych dopiero po II wojnie światowej, co wiązało się z udokumentowaniem zbrodni faszystowskich. W powstałym Państwowym Muzeum Auschwitz-Birkenau w Oświęcimiu od połowy lat 50. zaczęto na szeroką skalę zbieranie relacji więźniów. Uzyskane wywiady transkrybowano i przechowywano w formie pisemnych wspomnień. Obecnie muzeum ma zespół oparty na ustnych relacjach świadków „Oświadczenia” (161 tomów), relacje i zeznania zawarte w aktach radzieckiej Komisji Badania Zbrodni Niemiecko-Faszystowskich Agresorów (7 tomów), relacje robotników przymusowych (4 tomy), relacje dotyczące ewakuacji więźniów Konzentrationslager Auschwitz Birkenau w 1945 r. (7 tomów, 1144 strony), akta procesów przeciwko zbrodniarzom z załogi KL Auschwitz oraz wspomnienia i ankiety spisane przez więźniów. W przechowywanych w muzeum ponad 700 filmach dokumentalnych znajdują się wypowiedzi około 1300 więźniów oraz 100 nagrań filmowych całościowych relacji (czas emisji obejmuje 123 godziny) (Lewandowska 2011, 81-82). W 1955 r. powstało ogólnopaństwowe Archiwum Dokumentacji Mechanicznej przekształcone w 2008 r. w Narodowe Archiwum Cyfrowe. Najstarsze nagrania dźwiękowe pochodzą z 1889 r. Kolekcję można podzielić na dwie grupy: „Sekcja Polska Radia Wolna Europa” - 17 tys. nagrań oraz „Nagrania różnego pochodzenia”, przy czym 5\% obejmuje okres do 1939 r., 10\% pochodzi z czasów II wojny światowej, a 85\% to okres Polskiej Rzeczypospolitej Ludowej. Razem zebrano 40 tys. nagrań (Ibidem, 89). 
W latach 50. XX w. w Związku Sowieckim zaprzestano zbierania ustnych relacji od zwykłych ludzi, koncentrowano się na przekazach wybitnych działaczy państwowych. Wiadomo zatem, że były to teksty propagandowe i niezbyt zgodne z rzeczywistością. W następnej dekadzie zaczęły powstawać nielegalne stowarzyszenia i organizacje, których celem było gromadzenie informacji na temat znanych działaczy społecznych oraz badanie fonodokumentów jako nowego rodzaju źródła historycznego (Орлов 2014). W ramach podziemnej prasy w latach 70. i 80. ubiegłego wieku powstał pewien rodzaj alternatywnej historiografii, która opierała się przede wszystkim na osobistych wspomnieniach. Dysydentki i dysydenci nagrywali na taśmie rozmowy z osobami, które przeżyły stalinowskie obozy (Sherbakova 1992, 2000). Przy pomocy wspomnień - np. o kolektywizacji, trockistowskiej opozycji czy studenckich nielegalnych grupach z lat 40 . - próbowali przekazywać prawdziwe wersje historii lub patrzeć na nie $\mathrm{w}$ innym świetle niż oficjalna władza radziecka (Stephan 2004, 4).

Pojęcie ustnej historii weszło do sowieckiego naukowego dyskursu dopiero w połowie lat 70., ale dotyczyło sfery ściśle archiwalnej. Środowisko profesjonalnych badaczy zajmujących się historią mówioną, a szczególnie D. P. Ursu, znało światową literaturę dotyczącą tego zagadnienia, jak np. prace J. Vansiny, P. Thompsona czy A. Portelliego. Ursu próbował stworzyć narodową historiografię oral history, która wykorzystywałaby także rosyjską tradycję epicką. Dla przykładu podawał pisane kroniki starorosyjskie, a także późniejsze XVIII- i XIX-wieczne, które opierały się na przekazach ustnych. Pozytywnie odnosił się także do łączenia studiów nad folklorem ustnym i źródłami historycznymi, wskazując na konieczność interdyscyplinarności badań nad historią mówioną (Ursu 1989, 3-31). Inaczej do wykorzystania historii mówionej podchodził V. M. Surinov, który jako profesjonalny historyk upatrywał w relacjach oralnych przede wszystkim ich prawdziwości i zasadności w historycznych badaniach (Surinov 1976, 89-98).

W Polsce dopiero w 1968 r. głos w tej sprawie na forum naukowym zabrała historyk czasów powojennych K. Kersten, która uznała relacje ustne jako typ źródła historycznego (Kersten 1968, 316-329). Za nią poszli inni historycy i metodolodzy historii, np. T. Łepkowski, który odróżnił historię ustną przekazywaną w formie wywiadu, relacji lub rozmowy, świadomie zorganizowanej przez badacza, od tradycji ustnej, czyli spisanej w pamięci dziejów ludów (często plemiennych), i historii ludowej, inaczej historii „drugiego obiegu” opowiadanej w domach i kościołach (Łepkowski 1981, 441-443). Innym wybitnym badaczem był J. Topolski, który również wyróżnił trzy rodzaje źródeł oralnych: 1) informacje o przeszłości przechowywane w pamięci przez specjalnie powołanych do tego ludzi, typowe dla afrykańskiej tradycji ustnej; 2) informacje uzyskiwane przez historyka w toku wywiadów pochodzące z indywidualnej wiedzy udzielających wywiadu o rzeczywistości (to jest dzisiaj uznawane za rdzeń badań oral history); 3) informacje zawarte w źródłach pisanych, których powstanie było inspirowane (wywołane) przez historyka, 
np. spisywanie pamiętników na różnego rodzaju konkursy (Topolski 1983, 273-277). W latach 80. XX w. uznano także relacje ustne za nowe rodzaje dokumentów archiwalnych (Karczowa 1989; Robótka/Ryszewski/Tomczak 1989, 162-167; Robótka 1988, 112-115, 148-168).

\section{Działania organizacji pozarządowych w okresie przemian ustrojowych i państwowych}

Okres pierestrojki w Związku Sowieckim oraz Solidarności w Polsce spowodował szersze otwarcie na zbieranie relacji ustnych, będących zapisem pamięci drugiego obiegu, a więc historii nieoficjalnej, nienaznaczonej ideologią państwową. Pod koniec lat 80. XX w. zarówno w Rosji, jak i w Polsce zaczęto dużą wagę przywiązywać do tworzenia kolekcji relacji ustnych. Pierwsze impulsy do kreowania badań nad oral history po przełomie 1989 r. w Polsce i 1991 r. w Rosji przyszły właśnie ze strony organizacji pozarządowych, które zaczęły interesować się zapomnianymi grupami społecznymi i szczególnymi historycznymi wydarzeniami. Chodziło przede wszystkim o danie alternatywy dla oficjalnej narracji historycznej i politycznej (Melnikova 2006, 6-8).

W Warszawie w 1987 r. powołano Ośrodek Karta, który jako pierwszy zaczął nagrywać wywiady z Polakami represjonowanymi przez ZSRR, deportowanymi z Kresów Wschodnich, więźniami łagrów, żołnierzami podziemia antykomunistycznego (Lewandowska 2010a, 119). W 2003 r. z tego ośrodka wyodrębniła się nowa instytucja - Dom Spotkań z Historią (DSH) w Warszawie, do której przeniesiono archiwum zebranych relacji. Obecnie zbiory Ośrodka Karta i DSH liczą ponad 5,5 tys. opracowanych archiwalnie nagrań audio lub wideo, a także ponad 30 tys. zdjęć z rodzinnych albumów (http://dsh.waw.pl/historia-mowiona).

W Rosji natomiast najbardziej znanym stowarzyszeniem zajmującym się propagowaniem wiedzy historycznej i ochroną praw człowieka stał się założony w $1988 \mathrm{r}$. „Memoriał” (http://www.memo.ru). Ośrodek historii mówionej tej pozarządowej organizacji przeprowadził kilkaset wywiadów audio i wideo z byłymi więźniami obozów koncentracyjnych. Stowarzyszenie realizuje obecnie projekt „Ostatni świadkowie”. Jedna z jego organizatorek A. Koslowa mówi, że wielu świadków z zaniepokojeniem dopytuje się w siedzibie „Memoriału”, czy dokumenty i relacje, które przekazują do archiwum organizacji, nie trafią czasem w „niepowołane ręce”. Wartościowe są nie tylko relacje o szczegółach działań represyjnych, które w oficjalnych dokumentach władzy się nie pojawiają, lecz także informacje świadków o psychicznych skutkach represji (https://www.berliner-zeitung.de/ein-oral-history-projekt-aus-russland-bricht-das-schweigen-der-stalinzeit-antworten-auf-spaete-fragen-15059400). Memoriał organizuje też corocznie konkurs dla uczniów 
„Rosja. Wiek XX”, który ma pozyskać młodsze pokolenie do pracy badawczej ze źródłami mówionymi i prywatnymi dokumentami ich bliskich i znajomych (http:// urokiistorii.ru). Strona internetowa „Przypominam sobie” z opowiadaniami ustnymi i pisemnymi na temat II wojny światowej funkcjonuje w Internecie od $2000 \mathrm{r}$. (obecnie także w języku angielskim). Kierownik projektu A. Drabkin próbuje przechowywać i udostępniać wspomnienia weteranów wojennych w formie opowiadań. Jego grupa składa się z zaangażowanych współpracowników z różnych rosyjskich miast i z zagranicy, którzy do tej pory przeprowadzili ponad 300 wywiadów (https://iremember.ru).

Od przełomu XX i XXI w. rozpoczyna się okres powszechnego użycia mediów do popularyzacji badań naukowych oraz dokumentacji życia społecznego, w tym zasobów oral history. Bezpłatna przestrzeń informacyjna dała możliwości obcowania z e-kulturą, e-wiedzą i e-archiwami. Dla badań nad oral history ważne są następujące sfery e-kultury: elektroniczne formy nowoczesnej komunikacji (Internet, serwisy społecznościowe, fora i strony internetowe), elektroniczne dziedzictwo kulturowe (muzea online, galerie i wystawy zawierające m.in. fragmenty wywiadów), edukacja online, elektroniczne środki masowego przekazu (branżowe czasopisma online z zakresu historii mówionej), a także elektroniczne systemy odniesienia (archiwa, encyklopedie, słowniki i biblioteki) (Baeva 2017, 177).

\section{Inicjatywy uczelni wyższych po 1991 roku}

Po fazie tworzenia oddolnych inicjatyw obywatelskich przyszedł czas na sformalizowanie działań i nadanie im charakteru naukowego. W 1989 r., a więc jeszcze w schyłkowej fazie funkcjonowania Związku Sowieckiego, została zorganizowana w Kirowie pierwsza konferencja poświęcona problemom historii mówionej, wynikiem której było powstanie Towarzystwa Historii Mówionej. Zorganizowano potem kolejne ogólnorosyjskie konferencje. Dwie z nich odbyły się w 1989 i 1991 r. w Kirowie, natomiast kolejna w 1992 r. w Kaliningradzie (Rebrova 2009, 293).

Po upadku Związku Sowieckiego oral history przeżywała fazę konsolidacji. Naukowcy zdobywali doświadczenia, opracowywali techniki i programy przeprowadzania wywiadów. W tym okresie na kilku rosyjskich uniwersytetach utworzono pierwsze ośrodki badawcze historii mówionej (m.in. na Rosyjskim Państwowym Uniwersytecie Humanistycznym w Moskwie, przewodnictwo D. Chubova; na Ałtajskim Uniwersytecie Pedagogicznym w Barnaule, przewodnictwo M. Demin i T. Ščeglova; na Uniwersytecie Pedagogicznym w Vjatce, przewodnictwo V. Berlinskih; na Uniwersytecie Państwowym w Kaliningradzie, przewodnictwo J. Kostjašov). Wielu wykładowców opracowało kursy historii mówionej dla studentów historii i tworzyło specjalne plany nauczania (Ibidem). Zaczęto też szerzej interesować się 
historią kultury, wydarzeniami zorientowanymi na folklor, historią współczesną i antropologią, wykorzystując do badań przekazy ustne. W konsekwencji metoda ta systematycznie wkracza do tradycyjnych badań naukowych. W Rosji zostały stworzone trzy ważne ośrodki badawcze: 1) Centrum Wizualnej Antropologii i Oral History na Rosyjskim Państwowym Uniwersytecie Humanistycznym w Moskwie; 2) Centrum Oral History na Europejskim Uniwersytecie w Sankt Petersburgu oraz 3) centrum badawcze na Państwowym Uniwersytecie w Pietrozawodsku (Melnikova 2006, 7). Ponadto prężne badania i nauczanie prowadzi też Uniwersytet Pedagogiczny w Woroneżu. W Moskwie na Rosyjskim Państwowym Uniwersytecie Nauk Humanistycznych oral history należy do przedmiotów obligatoryjnych na kierunkach archiwistyka, historia i politologia. W zajęciach oprócz wykładów wprowadzających w terminologię, zadania i cele oral history, rozwój historii nauki i umiejscowienie dyscypliny w socjologicznym, antropologicznym, historycznym i etnologicznym krajobrazie naukowym wykładowcy odwołują się do studiów gender i badań totalitaryzmu. Zajęcia przechodzą w praktyczne ćwiczenia dotyczące różnych technik przeprowadzania wywiadów i metod ich analizy. Na zaliczenie studenci samodzielnie przeprowadzają wywiady, które są transkrybowane i wspólnie analizowane (Kuhlmann 2003).

Również w Polsce wykłada się historię mówioną na kilku uniwersytetach: Uniwersytecie Warszawskim (na kierunku historia, socjologia, antropologia kulturowa, kulturoznawstwo - D. Kałwa, P. Filipkowski, M. Rakoczy), na Uniwersytecie Jagiellońskim (na kierunku historia - M. Kurkowska-Budzan, M. Jarząbek), na Uniwersytecie Łódzkim (na kierunku socjologia - K. Kaźmierska) oraz na Uniwersytecie Warmińsko-Mazurskim (na kierunku historia - I. Lewandowska). Niestety, ośrodki naukowe w Polsce nie prowadzą projektów oral history instytucjonalnie. Czynią to jedynie poszczególni badacze w ramach własnych zainteresowań, ewentualnie we współpracy z organizacjami pozarządowymi.

W Rosji to właśnie ośrodki uniwersyteckie realizują projekty oparte na historii mówionej. Oto kilka przykładów. W 2001 r. ośrodek oral history na Uniwersytecie Europejskim w Sankt Petersburgu został wsparty przez Open Society Institute (Soros Foundation) i Centre for Oral History Indiana University (Indiana, USA). Ośrodek ma na celu rozwój badań i naukę analizowania wspomnień ustnych. Do kluczowych projektów ośrodka zaliczają się „«Bamovcy» o koleji bajkalsko-amurskiej: historia ostatniej budowy socjalizmu" (pod przewodnictwem T. Voronina, 2006-2007) i „Oblężenie w życiu i wspomnieniach mieszkańców Leningradu” (pod przewodnictwem E. Campbell, 2001-2002 i V. Kalendarova, 2002-2003). Efektem projektu dotyczącego Leningradu był m.in. tom zawierający opowiadania ustne o oblężeniu miasta (Rebrova 2009, 294).

W Woroneżu znajduje się regionalny ośrodek historii mówionej pod przewodnictwem N. Timofeeva. Ośrodek ten został utworzony w 2000 r., gdy Państwowy Uniwersytet Pedagogiczny w Woroneżu oferował fakultatywne seminarium „Obraz 
Niemiec i Niemców w oczach żołnierzy Wielkiej Wojny Ojczyźnianej”. Badacze tego ośrodka realizowali projekty takie jak „Człowiek i epoka: portrety współczesnych” (2008) oraz „Indywidualne wspomnienia i zbiorowa pamięć o okupacji i działaniach wojennych w regionie Woroneża 1942-1943" (2009). Wspólnie z Niemieckim Instytutem Historycznym w Moskwie organizowane są grupy robocze i konferencje tematyczne związane $\mathrm{z}$ historią mówioną. Ośrodek posiada stronę internetową zawierającą listę realizowanych projektów, konferencji i publikacji (http://www.historyvoice.ru).

W 2004 r. założono ośrodek historii mówionej na Państwowym Uniwersytecie w Pietrozawodsku (kierownictwo: A. Golubev). Naukowcy badają interakcję między państwem a społeczeństwem w epoce sowieckiej oraz historię Karelii jako sowieckiego terenu pogranicznego. Realizowali projekty, których celem było badanie zmian w życiu codziennym w Związku Sowieckim od lat 30. do 50. ubiegłego wieku, historii fińskiej imigracji do sowieckiej Karelii w latach 30., historii fińskiej okupacji Karelii i jej miejsca w pamięci ludzi. Efektem wywiadów jest seria monografii poświęconych historii mówionej, która ukazuje się od 2006 r. pod tytułem „Historia mówiona w Karelii”. Ośrodek ma własną stronę internetową, na której można znaleźć także inne informacje (http://oralhist.karelia.ru).

\section{Instytucje publiczne i niepubliczne oraz ich projekty}

O ile w Rosji historią mówioną zajmują się nieliczne stowarzyszenia i instytucje niepubliczne, o tyle w Polsce jest ich stosunkowo dużo. Oprócz wspomnianego już wyżej warszawskiego Ośrodka Karta i DSH bardzo prężnie działają: w Lublinie - Brama Grodzka Teatr NN (http://teatrnn.pl/historiamowiona) i we Wrocławiu - Centrum Historii Zajezdnia (http://www.zajezdnia.org/historia/swiadkowie-historii), które zorganizowały archiwa historii mówionych, realizują różne projekty dokumentacyjne, organizują warsztaty i konferencje poświęcone metodzie oral history. Projekty takie powstają też na użytek muzeów (Kuzko-Zwierz 2015, 91-110), m.in. Muzeum Powstania Warszawskiego (https://www.1944.pl/archiwum-historii-mowionej.html), Muzeum Solidarności w Gdańsku (http://www.ecs.gda.pl), Muzeum Historycznego w Ełku (http://muzeum.elk.pl/historia), Muzeum Pamięci Sybiru w Białymstoku (http://sybir.bialystok.pl/pl/strefapamieci/historiamowiona). Od 2009 r. działa Polskie Towarzystwo Historii Mówionej (http://pthm.pl), które organizuje coroczne warsztaty $\mathrm{z}$ historii mówionej i co kilka lat ogólnopolskie i międzynarodowe konferencje ${ }^{1}$.

${ }^{1}$ Współautorka tego tekstu również należy do tego towarzystwa i uczestniczy w organizowanych przez nie naukowych i warsztatowych spotkaniach (Lewandowska 2010b, 36-37). 
Warte podkreślenia jest posiadanie przez polskie środowisko historyków-oralistów własnego specjalistycznego pisma „Wrocławski Rocznik Historii Mówionej" (http://wrhm.pl), wydawanego od 2011 r. Funkcję redaktora naczelnego pełni W. Kucharski. Czasopismo jest miejscem prezentacji wieloaspektowych badań naukowych poświęconych metodologii oral history, źródłem informacji o aktualnie prowadzonych badaniach, projektach, organizowanych konferencjach i nowościach wydawniczych, których tematyka dotyczy oral history. Każdy numer zawiera ważne artykuły zarówno polskich, jak i zagranicznych badaczy, a także transkrypcje źródeł mówionych. Trzeba podkreślić, że rocznik wydawany jest przez stowarzyszenie Ośrodek „Pamięć i przyszłość”, a więc organizację społeczną, pozarządową i pozauczelnianą. Takiego branżowego pisma nie znaleziono jednak po stronie rosyjskiej.

W Rosji w 2004 r. biznesmen M. Prochorow założył pierwszą charytatywną fundację (http://www.prokhorovfund.ru/fund), która w 2010 r. zaczęła obsługiwać nowy program pod nazwą „Ustnaja istoria”. Jego celem jest stworzenie zbioru relacji mówionych naukowców i stworzenia publicznego archiwum dostępnego online. Obecnie zarchiwizowanych jest 275 wywiadów ze 158 rozmówcami (http:// oralhistory.ru). Podobną inicjatywę podjął Instytut Filozofii Rosyjskiej Akademii Nauk, który realizuje interaktywny projekt „Filozofia w przestrzeni publicznej”. $\mathrm{W}$ jego ramach nagrywa, archiwizuje i udostępnia online wypowiedzi filozofów bądź związane z filozofią, przybliżając to zagadnienie szerokiemu odbiorcy (https:// iphras.ru/vedeo_usthist.htm). Niestety, nie wszystkie projekty historii mówionej są udostępniane publicznie. Przykładem niech będzie realizowany w latach 2004-2005 przez Instytut Problemów Społeczeństwa Obywatelskiego międzynarodowy projekt „Żywe głosy historii”. Wzięło w nim udział 400 ośrodków z 85 rosyjskich miast. Współpracownicy tego projektu, najczęściej z organizacji młodzieżowych, nagrywali frontowych weteranów II wojny światowej oraz weteranów straży tylnej (Rebrova 2009, 298).

\section{Wybrane projekty międzynarodowe $z$ udziałem Rosji i Polski}

Do głównych projektów realizowanych w latach 2005-2006 w Rosji zaliczany jest projekt „Dokumentacja biograficznego wywiadu z byłymi robotnikami niewolniczymi i przymusowymi" (http://www.zwangsarbeit-archiv.de). Jego kierownikiem merytorycznym był niemiecki badacz A. Plato. Archiwum pod skróconą nazwą „Praca przymusowa 1939-1945” przypomina o ponad 20 mln ludzi, którzy musieli pracować dla nazistowskich Niemiec. Zarchiwizowano w nim prawie 600 rozmów z byłymi przymusowymi robotnikami z 26 krajów, które można - po uprzednim zalogowaniu się - odsłuchać w całości. Ponadto są tam transkrypcje, tłumaczenia, fotografie oraz krótkie biografie. Wywiady w 25 językach dostępne 
są również poprzez „Forced Labor 1939-1945” (angielski), „Принудительный труд 1939-1945” (rosyjski) i „Nucená práce 1939-1945” (czeski). Poniżej podano tylko podzbiory dotyczące Polski i Rosji: „Polska - Berliński Warsztat Historyczny” 11 osób udzielających wywiadu, „Polska - Karta, Warszawa” 62 osoby udzielające wywiadu, „Polska - Podgórski Poniatowa” 5 osób udzielających wywiadu; „Rosja - Akademia Moskwa” 10 osób udzielających wywiadu, „Rosja - Memoriał Moskwa” 35 osób udzielających wywiadu, ,Rosja - Memoriał Sankt Petersburg” 15 osób udzielających wywiadu, „Rosja - Regionalny ośrodek w Woroneżu” 10 osób udzielających wywiadu. Na podstawie zebranych relacji powstało kilka prac naukowych (Plato/Leh/Tonfeld 2008; Данченко 2012), a regionalny ośrodek historii mówionej w Woroneżu razem z Wolnym Uniwersytetem Berlińskim z myślą o rosyjskich szkołach rozwinął platformę online odnoszącą się do pracy przymusowej (https:// obuchenie-na-osnove-intervyu.org). Platforma „Обучение на основе интервью” jest od października 2017 r. dostępna dzięki Fundacji „Pamięć, odpowiedzialność i przyszłość". Kursy dla nauczycieli i seminaria wspierają rosyjskie szkoły przy korzystaniu z niej na zajęciach edukacyjnych.

Inny międzynarodowy projekt to „Mauthausen Survivors Documentation Project”, realizowany w latach 2002-2003 w kilkunastu krajach europejskich, Stanach Zjednoczonych, Kanadzie i Izraelu, w tym także w Polsce i Rosji. Ze strony polskiej realizował go Ośrodek „Karta”, mający duże doświadczenie w nagrywaniu relacji już od końca lat 80. ubiegłego wieku (Madoń-Mitzner 2011). „Ocaleni z Mauthausen to - jak pisał jeden z jego koordynatorów w Polsce P. Filipkowski - obok dokumentacji fundacji Spielberga, zapisującej doświadczenie Holokaustu, największy prowadzony w Europie program badawczy oparty na historii mówionej" (Filipkowski 2002, 133-135).

\section{Wybrane pozycje naukowe i popularnonaukowe wykorzystujące relacje ustne}

Jednym z wielu przykładów jest praca powstała jako efekt rosyjskiego projektu opartego o historyczne podłoże realizowanego przez Uniwersytet Państwowy w Kaliningradzie. Ukazuje ona obraz Prus Wschodnich w świetle relacji sowieckich migrantów, którzy osiedlili się na terenie dawnych terytoriów niemieckich, które po II wojnie światowej przypadły Związkowi Sowieckiemu, tj. w obwodzie kalinigradzkim (Vostochnaia Prussija 2002). W języku polskim ukazała się także publikacja dotycząca tych problemów, szczególnie poczytna wśród badaczy zajmujących się dziejami Prus Wschodnich (Kostiaszow 2000).

W 2003 r. Centrum Oral History na Europejskim Uniwersytecie w Sankt Petersburgu wydało bardzo ważną publikację „Khrestomatija po ustnoi istorii” [Reader on 
Oral History] autorstwa M. Loskutovej. Zawarto tam przekłady kilku znaczących artykułów badaczy zagranicznych stanowiących bazę dla badań nad oral history, tj. A. Portelliego, J. Vansiny, P. Thompsona, L. Passerini i innych. Przetłumaczono także w oddzielnych publikacjach książki P. Thompsona i J. Assmana. Oczywiście tego typu metodologicznych publikacji dla rosyjskich czytelników istnieje więcej (Melnikova 2006, 9).

Niestety w Polsce nie udało się do tej pory napisać ani oddzielnego podręcznika dotyczącego oral history, ani wydać zbioru ważnych tekstów. Prace nad tymi publikacjami trwają już kilka lat, efektu końcowego jednak nie widać. Powstają natomiast pojedyncze książki naukowe wykorzystujące tę metodę, które w części pierwszej, wprowadzającej, zwykle poświęcają znaczną cześć na charakterystykę metody. Są to prace poświęcone doświadczeniu II wojny światowej (Filipkowski 2010), życiu prywatnemu Polaków w okresie PRL-u (Klich-Kluczewska 2005), Polakom w Kazachstanie (Kudela-Świątek 2013), podziemiu zbrojnemu po II wojnie światowej (Kurkowska-Budzan 2009) czy też pojedynczym osobom, które odegrały ważną rolę w regionie (Lewandowska 2015). Po stronie rosyjskiej mamy zaś publikacje dotyczące doświadczenia osób represjonowanych w GUŁagu (Convery 2014, 107-108), donosicielom w okresie stalinowskim i ich wpływie na losy winnych, ale często i niewinnych, ludzi (Perks 2008, 107-108) czy też ciągle żywej pamięci obrońców Leningradu (Clapperton 2007, 49-60).

\section{Zakończenie}

Po analizie porównawczej stanu historii mówionej w Rosji i Polsce nasuwa się kilka refleksji. Jeżeli weźmie się pod uwagę historię badań nad tą metodą i zauważenie potrzeby zbierania relacji ustnych, w Rosji pojawiło się to już po rewolucji październikowej, a w Polsce dopiero po II wojnie światowej. W drugiej połowie XX w., kiedy dominował okres komunistyczny i ograniczenie swobody wypowiedzi, nastąpiło zahamowanie rozwoju tej metody. Pierwsze symptomy odwilży zauważyć można dopiero pod koniec lat 80., wtedy to powstały w Polsce Ośrodek „Karta”, a w Rosji zaś Stowarzyszenie „Memoriał”. Wraz z upadkiem komunizmu i Związku Sowieckiego nastąpiło duże przyspieszenie, które trwa do dzisiaj. Elementy podobne w obu krajach to występowanie badań oral history na uniwersytetach. Różnicą jest większe natężenie prac naukowych w Rosji, które koncentrują się w specjalnie do tego celu powołanych centrach akademickich. Natomiast polscy badacze prowadzą badania indywidualne, współpracując często z ośrodkami pozarządowymi. W obu krajach występują też stowarzyszenia i fundacje, które zbierają relacje, organizują archiwa społeczne i spotkania warsztatowe, publikują książki. Wydaje się jednak, że liczba i intensywność działań organizacji pozarządowych jest większa w Polsce niż w Rosji. W Polsce działa również Polskie Towarzystwo Historii Mówionej oraz 
wydawane jest specjalistyczne czasopismo „Wrocławski Rocznik Historii Mówionej”, które skupiają historyków-oralistów z całego kraju. W Rosji natomiast - najprawdopodobniej ze względu na olbrzymi obszar kraju - powstały regionalne centra badawcze, np. w Moskwie, Sankt Petersburgu, Woroneżu, Pietrozawodsku. Autorzy artykułu mają nadzieję, że w przyszłości uda się nawiązać wspólne kontakty między oralistami obu krajów.

\section{Bibliografia}

BAEVA, L. (2017), Values of Mediasphere and E-Culture. W: Przegląd Wschodnioeuropejski. XVIII/1, $173-184$.

Clapperton, J. (2007), The siege of Leningrad as sacred narrative: conversations with survivors. W: The Journal of Oral History Society. 35/1, 49-60.

CONVERY, D. (2014), Gulag voices: oral histories of Soviet incarceration and exile. W: The Journal of Oral History Society. 42/2, 107-108.

DANChenko, E. L. (2012), Batraki ponevole. Prinuditel'nyy trud ,vostochnykh rabochikh” v sel'skom khozyaystve natsistskoy Germanii (1941-1945 gg.). Voronezh. [Данченко, Е. Л. (2012), Батраки поневоле. Принудительный труд „восточных рабочих” в сельском хозяйстве нацистской Германии (1941-1945 гг.). Воронеж.]

FiLIPKowski, P. (2002), Ocaleni z Mauthausen. W: Karta. 34-35, 133-135.

Filipkowski, P. (2010), Historia mówiona i wojna: doświadczenie obozu koncentracyjnego w perspektywie narracji biograficznych. Wrocław.

Karczowa, H. (1989), Taśmoteka Archiwum Dokumentacji Mechanicznej w Warszawie. Dokumentacja dźwiękowa dotycząca lat 1901-1972. Przewodnik. Warszawa/Łódź.

Kersten, K. (1968), Relacje jako typ źródła historycznego W: Pamiętnik X Powszechnego Zjazdu Historyków Polskich w Lublinie, 17-21 września 1968 r. Referaty plenarne. Sekcje VII-XI. Warszawa, 316-329.

Klich-KluczewsKa, B. (2005), Przez dziurkę od klucza. Życie prywatne w Krakowie 1945-1989. Kraków.

Kostiaszow, J. W. (red.) (2000), Przesiedleńcy opowiadają. Pierwsze lata Obwodu Kaliningradzkiego we wspomnieniach i dokumentach. Olsztyn.

KudELA-ŚwiĄTEK, W. (2013), Odpamiętane. O historii mówionej na przykładzie narracji kazachstańskich Polaków o represjach na tle narodowościowym i religijnym. Kraków.

Kuhlmann, A. (2003), Zwischenbericht über den Aufenthalt an der Staatlichen Universität der Russischen Humanwissenschaften (RGGU), Moskau, im Rahmen des trilateralen Programmes „Transformation and Identities in European Societies” vom 7. Januar bis 25. März 2003. W: http:// www.trilat.uni-bremen.de/berichte/ZwischenberichtKuhlmann.pdf [dostęp 25.11.2017].

Kurkowska-Budzan, M. (2009), Antykomunistyczne podziemie zbrojne na Białostocczyźnie. Analiza współczesnej symbolizacji przeszłości. Kraków.

KuZko-Zwierz, K. (2015), Historia mówiona w muzeach. Przegląd projektów prowadzonych przez polskie placówki muzealne. W: Wrocławski Rocznik Historii Mówionej. V, 91-110.

ŁEPKOwSKI, T. (1981), Historia ustna i „historia ludowa”. W: Kwartalnik Historyczny. 2, 441-443.

LEWANDOWSKa, I. (2009), Historycy wobec metody oral history. Przegląd polskiej literatury naukowej. W: Świgoń, M. (red.), Historia - archiwistyka - informacja naukowa. Prace dedykowane Profesorowi Bohdanowi Ryszewskiemu. Olsztyn, 127-138.

LeWANDOWSKa, I. (2010a), Oral history in modern Poland - studies, educational projects, scientific associations. W: Narojczyk, K./Świgoń, M./Wolny, M. (red.), History, Archive Studies Information Science: methodological issues. Olsztyn, 115-124.

Lewandowska, I. (2010b), Polskie Towarzystwo Historii Mówionej (PTHM/POHA). W: Wiadomości Historyczne. II, 36-37. 
LEWANDOWSKa, I. (2011), Oral history we współczesnej Polsce - badania, projekty, stowarzyszenia. W: Wrocławski Rocznik Historii Mówionej. I, 81-103.

LEWANDOwsKa, I. (2015), Konserwatorskie zwierzenia. Rozmowy z Lucjanem Czubielem konserwatorem zabytków w Olsztynie 1956-1993. Wywiad-rzeka. Materiały źródłowe. Olsztyn.

Loskutova, M. (2003), Khrestomatija po ustnoi istorii. Sankt Petersburg.

MadoŃ-Mitzner, K. (oprac.) (2011), Relacje polskich więźniów obozów nazistowskich systemu Mauthausen-Gusen. Warszawa.

OrLov, I. B. (2014), Ustnaya istoriya. W: Alekseyeva, V. V. i dr. (red.), Teoriya i metodologiya istorii. Volgograd, 335-355. [Орлов, И. Б. (2014), Устная история. W: Алексеева, В. В. и др. (ред.), Теория и методология истории. Волгоград, 335-355.]

Perks, R. (2008), The whisperers: private life in Stalin's Russia. W: The Journal of Oral History Society. 36/2, 107-108.

Plato, A./Leh, A./Tonfeld Ch. (Hrsg.) (2008), Hitlers Sklaven. Lebensgeschichtliche Analysen zur Zwangsarbeit im internationalen Vergleich. Wien.

Rebrova, I. (2009), Oral History im heutigen Russland. W: BIOS [Zeitschrift für Biographiforschung, Oral History und Lebensverlaufsanalysen]. 22/2, 293-300.

Rово́тка, H.(1988), Metodyka archiwalna. Opracowanie dokumentacji geodezyjno-kartograficznej, technicznej, audiowizualnej (fotografii, filmów i mikrofilmów, nagrań). Toruń, 112-125, 148-162.

RовótкA, H./Ryszewski, B./TomczaK, A. (1989), Archiwistyka. Warszawa, 162-167.

Sherbakova, I. (1992), The Gulag in Memory. W: Passerini L. (ed.), Memory and totalitarism. Oxford.

Sherbakova, I. (2000), Nur ein Wunder konnte uns retten. Leben und Überleben unter Stalins Terror. Frankfurt am Main.

Stephan, A. (2004), Erinnertes Leben: Autobiographien, Memoiren und Oral History - Interviews als historische Quellen, 4. W: https://epub.ub.uni-muenchen.de/627/1/Stephan-Selbstzeugnisse. pdf_[dostęp 18.11.2017].

Topolski, J. (1983), Teoria wiedzy historycznej. Poznań, 273-277.

\section{Netografia}

http://dsh.waw.pl/historia-mowiona

http://muzeum.elk.pl/historia

http://oralhist.karelia.ru

http://oralhistory.ru

http://pthm.pl

http://sybir.bialystok.pl/pl/strefapamieci/historiamowiona

http://teatrnn.pl/historiamowiona

http://urokiistorii.ru

http://wrhm.pl

http://www.ecs.gda.pl

http://www.historyvoice.ru

http://www.memo.ru

http://www.prokhorovfund.ru/fund

http://www.zajezdnia.org/historia/swiadkowie-historii

http://www.zwangsarbeit-archiv.de

https://iphras.ru/vedeo_usthist.htm

https://iremember.ru

https://obuchenie-na-osnove-intervyu.org

https://www.1944.pl/archiwum-historii-mowionej.html

https://www.berliner-zeitung.de/ein-oral-history-projekt-aus-russland-bricht-das-schweigen-derstalinzeit-antworten-auf-spaete-fragen-15059400 